Chapter published in: Karine Tournier and Sol Marie Gayte (eds.) The Faces of Contemporary Populism in Western Europe and the US, Cham, Palgrave-MacMillan, 2021, pp. 165-180.

\title{
Economic Populist Attitudes in Western Europe and the United States
}

\author{
Gilles Ivaldi, CNRS-CEVIPOF, Science Po, Paris \\ gilles.ivaldi@ssciencespo.fr \\ Oscar Mazzoleni, IEP, University of Lausanne \\ oscar.mazzoleni@unil.ch
}

\begin{abstract}
The rise of populist actors is increasingly associated with economic issues such as welfare, redistribution and international trade. However, the link between populism and the economy remains unclear. This chapter argues the importance of a specific concept of economic populism whereby economic issues may be partially embedded into a populist frame. This frame may be expressed differently across contexts and it may also cross-cut traditional economic cleavages. Moreover, economic populism may be found among ordinary citizens in the form of a specific set of attitudes. Based on a recent comparative cross-sectional survey of citizens in France, Switzerland and the United States, we show that economic populism forms a common attitudinal dimension across these three countries, which is however differently distributed across the left-right axis and which manifests differently in relation to other important economic correlates of populism such as economic redistribution, welfare chauvinism and attitudes towards globalization, according to context.
\end{abstract}

\section{Introduction}

The rise of populism is one of the most significant phenomena in today's political world. In the last decade, parties labelled as 'populist' have gained significance in Europe and North America, populating both the left and right of the political spectrum and, as Brexit and the 2016 US presidential election illustrated, increasingly penetrating mainstream politics. 
Economic issues and material grievances are increasingly relevant to the understanding of the populist phenomenon ${ }^{1}$ In the context of economic globalization, economic issues such as welfare, redistribution and international trade, which are associated with feelings of economic insecurity, loss of status and rapid technological change in post-industrial societies, might be seen as relevant drivers of populism ${ }^{2}$. However, the link between populism and economics remains unclear. The interplay between economic factors and populism should be explored further by scholars, both theoretically and empirically, particularly in the field of electoral politics.

With a specific focus on the economic dimension of populism, this chapter builds on our previous work and argues the importance of a specific concept of economic populism ${ }^{3}$. While our previous work concerned the party supply of economic populism, here we are interested in the demand-side and explore citizens' attitudes. Accordingly, the chapter is organised as follows: the first section provides a definition of the concept of economic populism and explains the rationale for our comparative analysis; next, using empirical data from a cross-national survey in two Western European countries -France and Switzerland- and in the United States, we show that economic populism forms a consistent attitude that can be measured across different contexts and which operates alongside other established socio-economic correlates of populism.

\section{Economic Populism}

While the rise of populist actors is increasingly associated with economic issues such as welfare, redistribution and international trade ${ }^{4}$, we still need a better understanding of the link between populism and economics ${ }^{5}$.

\section{Left-right economic orientations and beyond}

The main definitions of populism in political science do not explicitly include a link to economics. Mudde defines populism as a "thin-centred" ideology, which "considers society to be ultimately separated into two homogeneous and antagonistic groups, 'the pure people' versus "the corrupt elite". Populist actors claim to represent the "ordinary people" and the latter is

\footnotetext{
${ }^{1}$ S. Otjes, G. Ivaldi, A. Ravik Jupskås, O. Mazzoleni, "It's not Economic Interventionism, Stupid! Reassessing the Political Economy of Radical Right-wing Populist Parties", Swiss Political Science Review, 24, 3 (2018): 270290.

2 D. Rodrik, "Populism and the Economics of Globalization", Journal of International Business Policy, 1,1-2 (2018): 12-33; J. Gest, T. Reny, J. Mayer, "Roots of the Radical Right: Nostalgic Deprivation in the United States and Britain", Comparative Political Studies, 51, 13 (2018): 1694-1719.

${ }^{3}$ G. Ivaldi, O. Mazzoleni, "Economic Populism and Sovereigntism. The economic supply of European Radical Right-wing populist parties", European Politics and Society, first online, (2019a) DOI: 10.1080/23745118.2019.1632583.

${ }^{4}$ Rodrik 2018.

${ }^{5} \mathrm{G}$. Magni, Inequality, immigrants, and selective solidarity: How economic disparity fuels cultural conflict, Paper presented at the Midwest Political Science Association Annual Congress, Chicago, 2018; M. Carreras, I. Y. Carreras, S. Bowler, "Long-Term Economic Distress, Cultural Backlash, and Support for Brexit", Comparative Political Studies, 52, 9 (2019): 1396-1424; L. McKay, "Left behind' people, or places? The role of local economies in perceived community representation", Electoral Studies, 60 (2019), 102046: 1-11; J. C. Hays, L. Junghyun, J.J. Spoon, "The Path from Trade to Right-wing Populism in Europe", Electoral Studies, 60 (2019): 1-14.

${ }^{6}$ C. Mudde, "The Populist Zeitgeist", Government and Opposition, 39 (2004): 542-563.
} 
given a positive moral connotation in opposition to the elite. According to Mény and Surel and Canovan, populists claim that the "true people" have been betrayed by elites and that a radical change is needed in order to restore the people's right ${ }^{7}$. Laclau argues that populism is a logic of discursive construction of two blocs, the "people" and their "opponents", which is situated in critical junctures ${ }^{8}$. While not excluding an economic dimension, these definitions imply that the economy may be considered a separate domain vis-à-vis populism.

Moreover, where the economic dimension is put into the picture, it is often taken as a proxy for the classic left-right ideological opposition between state and market, whereby party agendas, platforms and citizen's attitudes are almost exclusively seen through the lenses of the liberal versus interventionist-egalitarian cleavage. Following such assumptions, economic issues generally tend to be considered more relevant to populism on the left than on the right of the party spectrum. The main populist scholarship argues that right-wing populism primarily operates on the cultural dimension in relation to issues of immigration and multiculturalism ${ }^{9}$ while, on the left, populism is predominantly associated with socio-economic values and preferences for egalitarian economic policies ${ }^{10}$. Such asymmetrical view emphasizes also the vagueness and often contradictory supply of economic policies by right-wing populist parties as they need to address a heterogeneous set of socio-economic conditions and preferences amongst their supporters ${ }^{11}$.

While such perspectives make a significant contribution to our understanding of the variety of the populist phenomenon, they do not entirely allow to solve the puzzle of the relationship between populism and the economy. Recent literature suggests that economic grievances are a major factor of populist success, both left and right ${ }^{12}$. Populist actors mobilize on feelings of economic insecurity arising from globalization and rapid change in post-industrial societies ${ }^{13}$. They address a wide range of socio-economic issues both domestic and foreign, in connection with global challenges and international economic integration, showing an inclination towards protectionist policies. Meanwhile, there is substantial variation in those parties' socio-economic policies, which suggests that the political economy of populism may not necessarily align with traditional economic cleavages. Research suggests that the populist mobilization of economic and material grievances should simply not be reduced to traditional left-right or state-market oppositions ${ }^{14}$. It is therefore important that we explore further the relationships between

\footnotetext{
${ }^{7}$ Y. Mény, Y. Surel, Par le peuple, pour le peuple. Le populisme et la démocratie (Paris: Fayard, 2000); M. Canovan, The People (Cambridge: Polity Press, 2005).

${ }^{8}$ E. Laclau, On Populist Reason (London \& New York: Verso, 2005).

${ }^{9}$ C. Mudde. Populist Radical Right Parties in Europe (Cambridge: Cambridge University Press, 2007); H. G. Betz, "Facets of nativism: a heuristic exploration", Patterns of Prejudice, 53:2 (2019): 111-135; P. Norris, R. Inglehart, Cultural Backlash. Trump, Brexit, and Authoritarian Populism (Cambridge: Cambridge University Press, 2019).

${ }^{10}$ L. March, L., "From Vanguard of the Proletariat to Vox Populi: Left-Populism as a 'Shadow' of Contemporary Socialism", SAIS Review, 27, 1(2007): 63-77; P. Segatti, F. Capuzzi, F., "Five star movement, Syriza and Podemos: A Mediterranean model? In A. Martinelli, ed., Populism on the rise. Democracies under challenge? (Milan: Instituto per gli Studi di Politica Internazionale, 2017), 43-74.

11 J. Rovny, J. Polk, "Still blurry? Economic salience, position and voting for radical right parties in Western Europe", European Journal of Political Research, first online, 2019 doi: 10.1111/1475-6765.12356.

12 Rodrik 2018.

13 B. Bonikowski, "Three Lessons of Contemporary Populism in Europe and the United States", The Brown Journal of World Affairs, 23, 1 (2017): 9-24; R. Gidron, P. A. Hall, "The politics of social status: economic and cultural roots of the populist right", The British Journal of Sociology, 68, S1 (2017): 57-84.

${ }^{14}$ Otjes et al. 2018.
} 
economic grievances and issues, and provide alternative ways of thinking about the relationship between populism and the economy, which allow to go beyond traditional approaches.

\section{The economic populism framework}

We take our inspiration from Mény and Surel ${ }^{15}$ and argue that current populist claims, as expressed especially in Western countries, deploy an underlying master economic frame which is embedded into populist politics and which, as we argue below, shows variation in terms of the socio-economic policies that are associated with it. The general economic populist frame is based upon the idea that "true" people embodies an economic community who shares a common destiny, and whose material well-being and prosperity are in decline and/or at risk. The well-being of the "people" is presented as ignored or betrayed by the "elite". According to the economic populist frame, the "true' people is defined as a "virtuous" community of hardworking "makers", which is opposed to a 'corrupt' and essentially non-productive elite at the top of society. Finally, economic populism implicitly conveys a message of "nostalgia of the old good times"16 by referring to an idealized or "gold" period when economic well-being was predominant among the people, and which needs to be restored ${ }^{17}$.

Our main hypothesis is that, while following a similar logic, this broader master frame might be expressed differently across different Western contexts, partially cross-cutting traditional left-right economic cleavages. While previous research has identified economic populism as a core feature of radical right-wing populist (RRP) politics ${ }^{18}$, there is good reason to believe that economic populism may also find its way into left-wing politics, thus showing some commonalities across different manifestations of the populist phenomenon.

Such views do not necessarily imply that the left-right economic cleavage is obsolete, however. In fact, our second hypothesis is that economic populism may be expressed differently in relation to other important economic aspects that are usually linked to populism, such as welfare chauvinism, redistributive policies, and attitudes towards global trade. Welfare chauvinism tends to be strongly associated with right-wing authoritarian populism ${ }^{19}$, however not necessarily implying an opposition to globalization ${ }^{20}$. Moreover, it has been demonstrated that radical right-wing populist parties (RRPPs) vary greatly in terms of their supply of domestic economic policies ${ }^{21}$. Egalitarian economic policies and support for redistribution are, on the other hand, usually considered the most distinctive features of left-wing populism ${ }^{22}$. Left-wing actors have also become more prone to opposing economic globalization which they see as

\footnotetext{
${ }^{15}$ Mény and Surel 2000.

${ }^{16}$ H. G. Betz, C. Johnson, "Against the current - stemming the tide: the nostalgic ideology of the contemporary radical populist right", Journal of Political Ideologies, 9:3 (2004), 324.

${ }^{17}$ C. Thorleifsson C., "From coal to Ukip: the struggle over identity in post-industrial Doncaster", History and Anthropology 27, 5 (2016): 555-568; Gest, Reny, Mayer 2018.

${ }^{18}$ Ivaldi and Mazzoleni 2019a; G. Ivaldi, and O. Mazzoleni (2019b). "Economic Populism and Producerism: European Right-Wing Populist Parties in a Transatlantic Perspective', Populism, 2, 1 (2019b): 1-28.

${ }^{19}$ Norris and Inglehart 2019.

${ }^{20}$ E. Helleiner, A. Pickel, Economic nationalism in a Globalizing World (Itacha/London: Cornell University Press, 2005).

${ }^{21}$ Otjes et al. 2018, 285.

${ }^{22}$ S. M. Van Hauwaert, C. H. Schimpf, F. Azevedo, "The measurement of populist attitudes: Testing cross-national scales using item response theory”, Politics, online first (2019), doi.org/10.1177/0263395719859306.
} 
operating against the interests of the 'people', thus showing some convergence with the antiglobalization agenda of the populist right ${ }^{23}$.

\section{Economic populist attitudes in a comparative perspective}

To grasp economic populism and its related economic aspects, it is crucial to study resemblances and dissimilarities in a comparative perspective ${ }^{24}$. Our analysis focuses on two countries in Western Europe, namely France and Switzerland, which we contrast with the United States. These three countries show different party systems and political economies, as well as different levels of supranational integration and exposure to globalization, thus providing enough variance to test our proposition that economic populism may be a common feature in Western countries, however manifesting differently according to context.

In France, populism is found both left and right of the political spectrum. Left-wing populism is embodied by Jean-Luc Mélenchon's La France Insoumise (Rebellious France, LFI) while right-wing populism manifests itself predominantly in Marine Le Pen's Rassemblement national (RN, formerly Front National) ${ }^{25}$. In Switzerland, populism is mainly found to the right of the party system, in the Swiss People's Party (Schweizerische Volkspartei, SVP), which has been the dominant party in the Lower Chamber since the beginning of the $2000 \mathrm{~s}^{26}$. Finally, populism is a(n) historical feature of American politics and it has recently found its way in the 2016 presidential campaign, both to the left (Bernie Sanders) and right (Donald Trump) of the partisan spectrum, which makes the US a relevant case for our cross-continental analysis of economic populism ${ }^{27}$.

By selecting relatively different cases, at least among Western traditions, we try and explore similarities in the manifestations of economic populism. Economic populism may be analysed both in terms of party supply -i.e. messages spread by political actors- and voter demand -i.e. political attitudes of their supporters. This chapter looks more specifically at the demand-side of economic populism. Populist ideas resonate with large swathes of voters in Western societies where relevant populist parties and leader have been able to shape public opinion beyond the electoral arena. It is therefore crucial that we investigate whether economic populist attitudes exist among citizens. We may expect some citizens to hold economic populist attitudes that would make them more susceptible to a populist appeal. We ask in particular to which extent economic populism may be considered a specific set of attitudes among Western voters and to

\footnotetext{
${ }^{23}$ G. Ivaldi, M. E. Lanzone, D. Woods, "Varieties of Populism across a Left-Right Spectrum: The Case of the Front National, the Northern League, Podemos and Five Star Movement", Swiss Political Science Review, 23, 4 (2017): 354-376.

${ }^{24}$ Ivaldi et al. 2017; A. Santana, J. Rama, "Electoral support for left wing populist parties in Europe: addressing the globalization cleavage", European Politics and Society, 19, 5 (2018): 558-576; L. Bernhard, H. Kriesi, "Populism in election times: a comparative analysis of 11 countries in Western Europe", West European Politics, First online, 2019, DOI: 10.1080/01402382.2019.1596694; J. Rama, A. Santana, "In the name of the people: left populists versus right populists", European Politics and Society, 2019, DOI: 10.1080/23745118.2019.1596583.

${ }_{25}$ G. Ivaldi, G., "Populism in France", in D. Stockemer (ed.). Populism around the World: A Comparative Perspective (Cham: Springer, 2018): 27-48.

${ }^{26}$ O. Mazzoleni, "Political Achievements, Party System Changes and Government Participation: the Case of the 'New' Swiss People's Party”. In A. Zaslove, S. Wolinetz, eds., Absorbing the Blow : Populist Parties and their Impact on Parties and Party Systems (London: Rowman \& Littlefield International/ECPR Press, 2018): 83-102.

${ }^{27}$ K. R. Hawkins, R. Dudley, J.W. Tan, "Made in USA: Populism Beyond Europe", in A. Martinelli (ed.), Beyond Trump. Populism on the Rise (Novi Ligure: Edizioni Epoké-ISPI, 2016): 93-110; Bonikowski 2017; J. E. Oliver, W. M. Rahn, "Rise of the Trumpenvolk: Populism in the 2016 Election", ANNALS, AAPSS, 667 (2016): 189-206; Ivaldi and Mazzoleni 2019b.
} 
which extent such attitudes interact with other established socio-economic correlates of populism.

\section{Data and Methods}

Our analysis is based upon a cross-national survey conducted in France, Switzerland and the United States among representative national samples of the voting-age population. The survey was conducted online by YouGov in April 2019. Participants were selected by the polling company from their national panels recruited via the internet. The survey used quota-sampling based on gender, age, occupation and type of municipality with regional/state stratification. Potential 'speeders' who had completed the questionnaire in less half the median time were excluded, resulting in final analytical samples of 1,932, 2,062 and 2,093 respondents in France, Switzerland and the United States, respectively.

To measure economic populism, we use five items. The first three items reflect the idea of the "people" as an economic community of hardworking "makers", and risk for their well-being. The last two items concern the attribution of responsibility to the elite for the decline of the well-being of the people and claim to recover popular sovereignty to protect its interests.

- "In this country, one does not really care about people who work hard"

- "The overall economic well-being of this country has declined"

- "Today in [COUNTRY], many economic decisions are made without considering the interests of the people"

- "The government in this country does not really care about the people's living standards"

- "Citizens should have more say in the important decisions for our country"

In line with recent studies of populist attitudes ${ }^{28}$, we use Item Response Theory (IRT) analysis to assess the measurement validity of our scale of Economic Populism and examine IRT properties of unidimensionality, local independence and monotonicity ${ }^{29}$. The five economic populism items are combined in a single attitudinal dimension using an IRT score from a Graded Response Model (GRM) which we take as our dependent variable.

The analysis is performed by means of a series of linear regression models which include standard socio-demographics i.e. gender, age, education and occupation. Age is used as a continuous variable. Since we suspect that its effect may be curvilinear, we include a squared term in the models. For education, we use a three-group variable, with low, middle and high education. Occupation is based on the five-class version of the European Socio-economic Classification (ESeC), which is a well-documented standard ${ }^{30}$ and which has the following classes: managerial, administrative and professional occupations; intermediate occupations;

\footnotetext{
${ }^{28}$ Van Hauwaert et al. 2019.

${ }^{29}$ Unidimensionality means that only one latent variable is required to explain the association between item scores. Local independence (conditional association) implies that items are associated only via the latent dimension. Monotonicity means that the probability of endorsing a 'correct' response option increases with increasing levels of the latent construct.

${ }^{30}$ Rose, D. and Harrison, E. (eds), Social Class in Europe: An Introduction to the European Socio-economic Classification (London: Routledge, 2010).
} 
small employers and own account workers; lower supervisory and technical occupations and semi-routine and routine occupations.

We then add attitudinal and political controls, namely political affiliation (left right ideology) and a set of economic and cultural correlates of populism, i.e. economic redistribution, welfare chauvinism - that is the belief that access to the welfare state should be restricted to natives-, which is a crucial component of radical right-wing populist ideology, and attitudes towards globalization which are commonly seen as drivers of the populist support both left and right ${ }^{31}$.

\section{Results}

The analysis confirms our first hypothesis that economic populism can be constructed as a single latent attitudinal dimension across our three countries and that economic populist attitudes are shared by ordinary citizens across different contexts. The scale has high internal coherence, and it meets fundamental IRT assumptions of unidimensionality, local independence of items and monotonicity in each of our cases. Coefficients of homogeneity in France and Switzerland suggest a strong scale $(\mathrm{H}>0.5)$. In the United States, the coefficient for the scale is 0.41 (s.e. $=0.012$ ) which indicates a moderate scale $(0.4<\mathrm{H}<0.5)^{32}$. Our scale shows good reliability across all three samples with Cronbach Alphas all above the 0.7 cut-off. In each country, we compute an IRT score of Economic Populism, which we estimate from a Graded Response Model (GRM) for polytomous items ${ }^{33}$. The IRT score provides a standardized measure of Economic Populism (mean $=0$ and $\mathrm{sd}=1$ ), which we take as our DV in the following analyses.

This first raises the question of which social groups and categories may be most prone to economic populist attitudes. To answer this question, we run three linear regression models one for each country- and test the significance of standard socio-demographic variables, namely gender, age, education and occupation (see Table 1.1). As can be seen, while we find significant differences of economic populism across social groups, a strict socio-demographic model has little explanatory power, with $\mathrm{R}^{2}$ of $0.05,0.10$ and 0.03 in France, Switzerland and the United States respectively.

Table 1.1 Base model of economic populism in France, Switzerland and the United States

IRT Score of Economic Populism

\footnotetext{
${ }^{31}$ We use two different items to measure pro-redistribution attitudes among citizens: "To reduce inequality, one should take from the rich to give to the poor"; "It is the government's responsibility to ensure a decent standard of living for all". Attitudes towards economic globalization are measured from the items: "Globalization is an opportunity for economic growth in [COUNTRY]"; "Trade with other countries leads to jobs creation". We use the following items for welfare chauvinism: "Immigration is good for the economy"; "Immigrants bring in more than they take out"; "Immigrants who work hard should be allowed to stay"; "Priority should be given to nationals over foreigners in jobs".

32 Bootstrapped polychoric inter-item correlations are significant and positive for pairs of items across each country, and -with the exception of one pair in the French data- they are all below 0.8, which suggests local independence. Moreover, we do not find any serious violation of monotonicity.

${ }^{33}$ Van Hauwaert et al., 2019.
} 


\begin{tabular}{lccc}
\hline Female (ref=male) & $0,25(0,04)^{* * *}$ & $0,11(0,04)^{* *}$ & $0,16(0,04)^{* * *}$ \\
Age & $1,41(0,96)$ & $4,71(0,91)^{* * *}$ & $2,41(0,94)^{*}$ \\
Age squared & $-4,24(0,91)^{* * *}$ & $-6,47(0,89)^{* * *}$ & $-2,97(0,94)^{* *}$ \\
Education + (ref=Educ-) & $-0,11(0,05)^{*}$ & $-0,29(0,06)^{* * *}$ & $-0,05(0,05)$ \\
Education ++ (ref=Educ-) & $-0,27(0,06)^{* * *}$ & $-0,33(0,05)^{* * *}$ & $-0,01(0,05)$ \\
Intermediate occupations (Ref=Professionals) & $0,09(0,06)$ & $0,12(0,06)^{*}$ & $0,17(0,07)^{*}$ \\
Small employers and own account workers & $0,02(0,07)$ & $0,06(0,06)$ & $-0,08(0,06)$ \\
Lower supervisory and technical occupations & $0,20(0,06)^{* *}$ & $0,26(0,06)^{* * *}$ & $0,13(0,07)$ \\
Semi-routine and routine occupations & $0,17(0,07)^{* *}$ & $0,29(0,07)^{* * *}$ & $0,23(0,07)^{* * *}$ \\
Intercept & $-0,09(0,06)$ & $0,003(0,05)$ & $-0,13(0,05)^{*}$ \\
& & & 1890 \\
\hline Observations & 1905 & 2037 & 0,03 \\
R ${ }^{2}$ & 0,06 & 0,10 & 0,03 \\
Adjusted R & 0,05 & 0,10 & $0,89(\mathrm{df}=1880)$ \\
Residual Std. Error & $0,90(\mathrm{df}=1895)$ & $0,88(\mathrm{df}=2027)$ & ${ }^{*} \mathrm{p}<0,05 ;{ }^{* *} \mathrm{p}<0,01 ;{ }^{* * *} \mathrm{p}<0,001$ \\
F Statistic & $13,30^{* * *}(\mathrm{df}=9 ; 1895)$ & $25,10^{* * *}(\mathrm{df}=9 ; 2027)$ & $6,78^{* * *}(\mathrm{df}=9 ; 1880)$ \\
& & Linear regressions \\
\hline Notes: & & Std errors between brackets \\
& & YouGov survey, April 2019
\end{tabular}

The analysis shows commonalities across our three countries. First, women seem to be more prone to economic populism than men, which is surprising as populism is generally regarded as a predominantly male phenomenon, particularly in its radical right-wing variant. Age is a significant factor across all three countries: as anticipated, in Switzerland and the US, the effect of age is curvilinear with support for populism being lower amongst both the younger and older citizens. In France, the effect of age is primarily found amongst older citizens who are significantly less prone to economic populism.

In our two European countries, economic populism is significantly associated with education, and is predominantly found amongst the less educated i.e. those without a Baccalauréat (France) or matura (Switzerland). Citizens with secondary and tertiary education are on the other hand less likely to show economic populist attitudes. In contrast, in the United States, we find no such evidence of an educational cleavage underlying economic populism.

Finally, economic populism is distributed across different occupational groups in our three countries. In France, economic populism is primarily found in the lower social strata, amongst lower supervisory and technical, semi-routine and routine occupations, while it has a more 'middle class' basis in the US and in Switzerland where economic populist attitudes are also more pronounced amongst respondents in clerical and intermediate occupations.

We then turn to full models that include left-right self-placement and other attitudinal correlates of populism. This second set of linear regressions allows to test the relationship between economic populist attitudes -as our DV- and other important political and economic aspects which may be related to populist claims (table 1.2). The models find significant effects of socio- 
political and economic attitudes on levels of economic populism, with higher $\mathrm{R}^{2}$ of 0.31 (France), 0.26 (Switzerland) and 0.17 (USA) respectively.

We see important commonalities between our two European cases. In both France and Switzerland, economic populism is strongly and positively associated with welfare chauvinism, negative attitudes towards economic globalization and, most evidently, preferences for economic redistribution. While redistribution has also a strong effect in the United States, we find no relationship between economic populism and welfare chauvinism nor views of economic globalization in the American context.

Table 1.2 Full model of economic populism in France, Switzerland and the United States

\begin{tabular}{|c|c|c|c|}
\hline & \multicolumn{3}{|c|}{ IRT Score of Economic Populism } \\
\hline & France & Switzerland & USA \\
\hline Female (ref=male) & $0,20(0,05)^{* * *}$ & $0,07(0,04)$ & $0,08(0,05)$ \\
\hline Age & $1,53(1,04)$ & $2,92(0,96)^{* *}$ & $6,74(1,09)^{* * *}$ \\
\hline Age squared & $-2,93(0,98)^{* *}$ & $-3,89(0,96)^{* * *}$ & $-2,60(1,05)^{*}$ \\
\hline Education + (ref=Educ-) & $0,02(0,06)$ & $-0,13(0,06)^{*}$ & $0,07(0,06)$ \\
\hline Education ++ (ref=Educ-) & $0,01(0,06)$ & $-0,12(0,05)^{*}$ & $0,05(0,06)$ \\
\hline $\begin{array}{l}\text { Intermediate } \\
\text { (Ref=Professionals) }\end{array}$ & $0,02(0,07)$ & $0,12(0,06)$ & $0,13(0,08)$ \\
\hline Small employers and own account workers & $0,13(0,07)$ & $0,03(0,06)$ & $-0,08(0,06)$ \\
\hline Lower supervisory and technical occupations & $0,06(0,07)$ & $0,13(0,07)$ & $0,17(0,07)^{*}$ \\
\hline Semi-routine and routine occupations & $0,08(0,07)$ & $0,13(0,07)$ & $0,25(0,07)^{* * *}$ \\
\hline Left-Right & $0,01(0,01)$ & $0,04(0,01)^{* * *}$ & $-0,02(0,01)$ \\
\hline Welfare Chauvinism & $0,11(0,02)^{* * *}$ & $0,13(0,02)^{* * *}$ & $0,04(0,02)$ \\
\hline Redistribution & $0,26(0,02)^{* * *}$ & $0,23(0,01)^{* * *}$ & $0,18(0,02)^{* * *}$ \\
\hline Globalization positive & $-0,09(0,02)^{* * *}$ & $-0,05(0,02)^{* *}$ & $0,02(0,02)$ \\
\hline Intercept & $-1,71(0,15)^{* * *}$ & $-1,65(0,15)^{* * *}$ & $-1,00(0,17)^{* * *}$ \\
\hline Observations & 1243 & 1498 & 1347 \\
\hline $\mathrm{R}^{2}$ & 0,32 & 0,26 & 0,18 \\
\hline Adjusted $\mathrm{R}^{2}$ & 0,31 & 0,26 & 0,17 \\
\hline Residual Std. Error & $0,77(\mathrm{df}=1229)$ & $0,79(\mathrm{df}=1484)$ & $0,81(\mathrm{df}=1333)$ \\
\hline F Statistic & $44,20^{* * *}(\mathrm{df}=13 ; 1229)$ & $41,00^{* * *}(\mathrm{df}=13 ; 1484)$ & $22,70^{* * *}(\mathrm{df}=13 ; 1333)$ \\
\hline \multirow[t]{4}{*}{ Notes: } & \multicolumn{3}{|c|}{${ }^{*} \mathrm{p}<0,05 ;{ }^{* *} \mathrm{p}<0,01 ;{ }^{* * *} \mathrm{p}<0,001$} \\
\hline & \multicolumn{3}{|l|}{ Linear regressions } \\
\hline & \multicolumn{3}{|c|}{ Std errors between brackets } \\
\hline & \multicolumn{3}{|c|}{ YouGov survey, April 2019} \\
\hline
\end{tabular}

The effect of left-right self-placement also seems to be dependent upon national context. While in Switzerland economic populism seems to be mostly a right-wing phenomenon -as indicated by the positive correlation with the left/right self-placement variable in the model-, we find no significant effect in the other two countries, which suggests that economic populism may spread across the entire political spectrum. Since we suspect a possible curvilinear relationship in the 
French and American cases, we run our full model again including a squared term for left/right placement and find significant effects ${ }^{34}$.

The effects for France and the United States are shown in Figure 1. In France, the quadratic term is strongly positive, which corroborates that the effect of left-right ideologies is clearly more pronounced at both extremes of the political scale; in the United States, we find that both parameters are significant, with a negative sign for left-right self-placement, which suggests that economic populism is found at both ends of the spectrum, yet at a relatively higher level to the left of the ideological axis. As Figure 1 illustrates, the U-shaped relationship in the American case is however much less pronounced than in France.

\section{Figure 1. Economic Populism and left/right placement in France and the United States*}

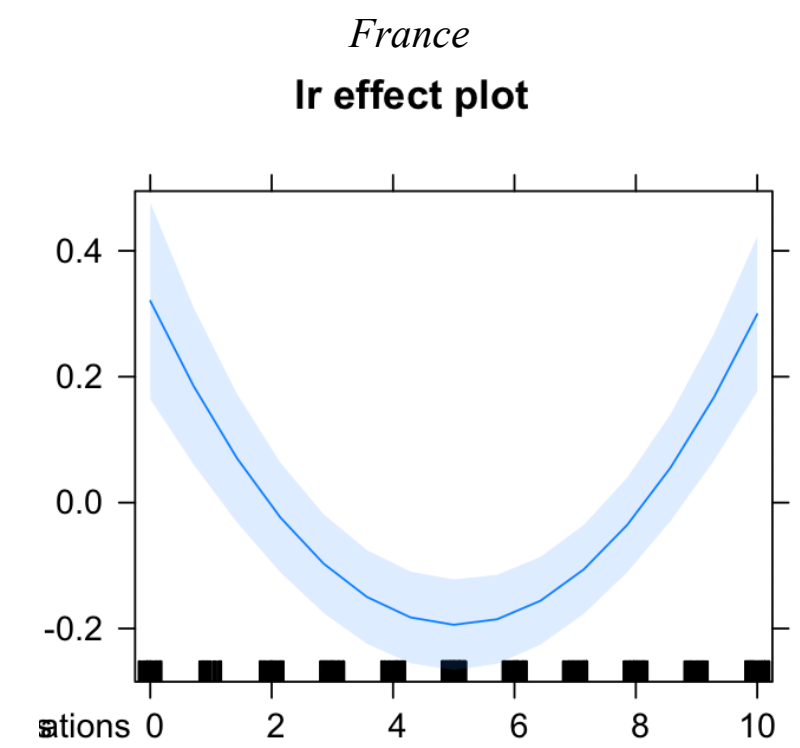

\section{United States \\ Ir effect plot}

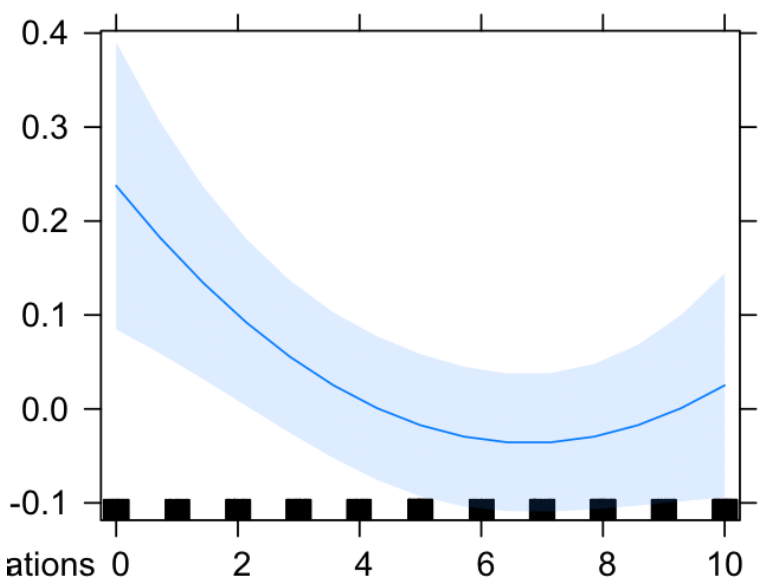

*Based on full models in Table 1.2, including a squared term for left-right self-placement.

\section{Conclusion}

This chapter has highlighted the economic dimension of populism, showing the importance of a more systematic analysis of the interplay between economic issues and grievances, on the one hand, and populism, on the other hand. While populism is usually presented as a phenomenon or concept distinct from the economic dimension, we have argued in this chapter that some economic aspects should be considered inherent in current populist frames, as they manifest in particular across Western countries. Material grievances, feelings of economic anxiety and social inequalities form part of a consistent economic populist frame which constructs its people

\footnotetext{
${ }^{34}$ In France, the coefficients and standard errors for left /right placement are as follows: 1.14 (1.0) n.s., 6.8 $(0.84)^{* * *}$; in the United States, the coefficients are: $-2.3(1.2)$ significant at the 0.1 level; $2.3(0.9)^{*}$.
} 
as a community of producers who share a common destiny and whose well-being is in decline and/or at risk, and needs to be restored.

Economic populist frames are key to the mobilization of voters by populist parties, but, as this chapter has demonstrated, such frames may also lay the basis for a common attitudinal feature amongst ordinary citizens. Economic populist attitudes can be found among large swathes of citizens in Western societies, making those citizens potentially more susceptible to a populist appeal. By looking more specifically at the demand-side of economic populism, this chapter has first illustrated some commonalities in the socio-demographic and educational drivers of economic populism. Young people, women and, most evidently in Europe, less so in United States, low-educated citizens are more likely to exhibit economic populist attitudes. This is consistent with previous research on voting behaviour, which provides evidence that lesseducated people are generally more attracted to populism ${ }^{35}$.

Turning to attitudinal drivers, this chapter has examined attitudes towards welfare chauvinism, redistributive policies and international trade, and found significant differences in the manner in which each of those may relate to economic populism. As our findings indicate, economic populism should not be confused with other economic issues such as the state-market opposition, which are traditionally associated with populism. The intersection between economic populism and attitudes such as welfare chauvinism and opposition to globalization should be regarded as context dependent. Let us note also that the different economic aspects that we have considered in this chapter do not represent a single phenomenon, for instance under the generic opposition between state and market, and they may not all have the same relevance to our understanding of economic populism across different contexts. As illustrated by our findings, economic redistribution may be seen as a strong correlate of economic populism across our three countries, while we see differences in the relationships between economic populism, welfare chauvinism and attitudes towards globalization in the United States when contrasted with our two European cases, again pointing to the importance of national contexts and economic traditions. Such importance is revealed further in the analysis of the distribution of economic populist attitudes across the left-right axis. Our findings provide empirical evidence that economic populism may find its way into both left and right-wing politics, again according to context, political supply by actors and economic traditions and legacies.

While this contribution has shed some light on how economic issues may be imbricated into populism, we have so far limited ourselves to exploring the socio-demographic drivers of economic populist attitudes and how such attitudes may relate to other important attitudinal features. A crucial future research agenda should concern the effect of economic populist attitudes on voting preferences, and their relevance to populist electoral support across both the left and right of the political spectrum. Moreover, this contribution has essentially built and expanded on our previous work regarding the supply of economic populism by RRPPs in Western Europe and the United States ${ }^{36}$. As our findings here suggest, we should turn our attention to how economic populist attitudes may contribute to explain voter preferences in contexts where populism manifests itself also to the left of the party system.

\footnotetext{
${ }^{35}$ Norris and Inglehart 2019, 135.

${ }^{36}$ Ivaldi and Mazzoleni 2019a; 2019b.
} 